\title{
Authors of Articles in Vol. II, No. 2
}

G. M. MEREDITH-OWENS, Professor in the Department of Islamic Studies, University of Toronto.

ALEXANDER NADSON, Headmaster of St Cyril's School, Finchley.

C. SIPOVIC, Bishop of Mariamme, Apostolic Visitor of Byelorussians.

H. PICHURA, nom de plume of Guy de Picarda, Director of the Marian House Choir, Finchley, and Honorary Secretary of the AngloByelorussian Society. 